\title{
Service Multinational Enterprises and Linkages Development in Pakistan
}

\author{
Zaheer Khan $(\bowtie)$ \\ Reader (Associate Professor) in International Business \\ Kent Business School \\ University of Kent, Canterbury CT2 7NZ, United Kingdom \\ email: khan.zaheer@gmail.com \\ Jeong-Yang Park
}

Assistant Professor of International Business Strategy

Nottingham University Business School, the University of Nottingham, United Kingdom

email: jeong-yang.park@,nottingham.ac.uk

Pervaiz Akhtar

Senior Lecturer (Associate Professor) in Supply Chain/Logistics/Operations Management, The Logistics Institute, Hull University Business School, The University of Hull, Hull, UK Email: Pervaiz.Akhtar@hull.ac.uk

Note: This is a pre-print non-publisher post peer review version

please cite: Zaheer Khan, Jeong-Yang Park, Pervaiz Akhtar (2016), Service Multinational Enterprises and Linkages Development in Pakistan, Canadian Journal of Administrative

Sciences, forthcoming.

\begin{abstract}
The development of various types of linkages is key for understanding the impact of multinational enterprises (MNEs) on the economic development of host markets. By utilizing qualitative research approach, this paper investigates the linkages creation by IT MNEs in Pakistan. The findings suggest that these MNEs have created various linkages such as management, technological, diversification and financial linkages. The creation of these linkages was contingent and co-determined by the MNEs' investment motives, their mandates and embeddedness in the host market as well as the local technical capability. The paper highlights the contributions and the implications of these linkages.
\end{abstract}

Keywords: FDI; IT industry; linkages; Pakistan; Service MNEs 


\section{INTRODUCTION}

Linkages are created by multinational enterprises (MNEs) when they develop various forms of collaborations and partnerships with local firms in the host market directly or indirectly (Altenburg, 2000; Forsgren, Holm \& Johanson, 2005; Lall, 1980; Miozzo \& Yamin, 2012). Research highlights the importance of such linkages for the local economic development of host market, as well as their impact on the capability development of local firms (Forsgren, Holm \& Johanson, 2005).

Due to the knowledge transfer potential of foreign direct investment (FDI), policy makers from a number of economies are promoting investors' friendly policies and various incentives to attract MNEs in their markets (e.g. offering 100\% equity to MNEs, repatriation of profit, free trade zones and tax incentives, among others), because the extant literature has highlighted its positive effect on the economic development of host markets (Blomström \& Kokko, 1998; Cheng, 2006; Ghauri \& Firth, 2011; Giroud, 2007; Keller \& Yeaple, 2009; Meyer, 2004; Xu, 2000).

Indeed FDI has both direct and indirect effects on host markets. Its direct effects are in the forms of employment generation, trade and capital, whereas indirect effects may include spillover taking place from MNEs to local firms in the form of labour mobility, imitation, and competition in the host markets (Dunning \& Lundan, 2008; Pavlínek \& Žížalová, 2014). Some studies have even questioned the positive influence of MNEs on host markets and have painted negative consequences of MNEs investment for the host markets. For example, researchers have noted that local firms loose out to MNEs by indicating both the 'crowding out' and 'market stealing impact' of MNEs on host markets (Aitken \& Harrison, 1999; Chang, 2004; Haddad \& Harrison, 1993).

Recently, the emerging and developing economies of Asia have been the popular destinations for the MNEs and these economies are increasingly relying on the MNEs for 
their economic development (UNCTAD, 2014). Against this backdrop, scholars have been suggesting the need to examine the impact and linkages between MNEs and local firms in the host market (UNCTAD, 2001; Yamin \& Sinkovics, 2009). The influence of MNEs on the economic development of host markets has been one of the key subjects of scholarly attention and specifically, the role of FDI in the development of emerging economies has been highlighted to be one of the main factors for knowledge transfer and spillovers in host markets (e.g., Ghauri \& Firth, 2011; Ha \& Giroud, 2015; Khan, Lew \&Sinkovics, 2015a; Park \& Ghauri, 2011; Smeets, 2008).

Despite the contributions of existing studies, there remain a number of contextual and theoretical gaps in the literature requiring a closer examination of the real impact of MNEs in the host economy, particularly in the context of emerging markets (Yamin \& Sinkovics, 2009). The contextual gaps contain a lack of research on the impact of FDI in Pakistan and there is a paucity of research focusing on the emerging economies at the periphery which are going through late-liberalization waves (e.g., Iguchi, 2012; Khan, Shenkar \& Lew, 2015b; Santangelo, 2009). Thus, the objective of this paper is to investigate one such example of a late liberalizing emerging economy- Pakistan.

Though the impact of MNEs' inward investment on host economies has been extensively studied since the 1960 s, there have been a few attempts to examine the impact of MNEs in Pakistan (e.g., Khan et al., 2015b). The utilisation of resources for increasing productive capability in order to promote economic development in Pakistan is seen to be limited by the scarcity of domestic capital (Khan \& Nawaz, 2010). Lack of domestic capital in Pakistan led the government to initiate a number of liberalisation policies to attract FDI. In this context, by focusing on late liberalizing market of Pakistan, this study generates in depth analysis on linkage formation, as several scholars have indicated that emerging markets tend to gain a higher level of linkage formation and learned more from MNEs than developed 
markets (Ghauri \& Firth, 2011; Hansen, Pedersen \& Petersen, 2009; Jindra, Giroud \& ScottKennel, 2009). Given that emerging markets have abundant skilled and unskilled human resources as well as natural resources, Ghauri and Firth (2011) indicate the positive prospect of innovation that arises from emerging markets. The potential for increasing the prospect of linkage formation in the emerging markets is associated with the level of economic development (Giroud, 2003).

Above all, theoretical gaps include a limited research looking at the service industry and the service sector is noted to be following a footlooseness strategy (Miozzo \& Grimshaw, 2008). Majority of the existing studies have been on the manufacturing MNEs and less attention has been devoted to the service multinationals, including IT MNEs (Kundu \& Merchant, 2008; Lahiri, Elango \& Kundu, 2014; Miozzo \& Grimshaw, 2008; Miozzo, Yamin \& Ghauri, 2012). The development of linkages between MNEs and local firms is essentially contingent and co-determined by different forms of industry contexts thus leading to the development of diverse patterns of linkages in host economies. As a result, empirical research demonstrates that the development of linkages in service and manufacturing industries tend to display different forms, patterns and characteristics. Typically, the majority of existing studies have extensively focused on understanding the formation of vertical linkages between MNEs and local firms in the host markets. These include value chain relationships such as backward (sourcing) and forward (distribution) linkages. For the service industry, research tends to focus either on forward or backward linkage effects whereas in the case of manufacturing industry, both forward and backward linkage effects tend to be examined concurrently (Nicolini \& Resmini, 2010; Javorcik, 2004). Despite the importance of such developments, little empirical research has focused on these aspects in the IT service industry (e.g. Ghauri \& Firth, 2011). 
In order to address the above gaps, this paper draws its arguments from the development economics and international business (IB) literature to understand the development of linkages by the IT MNEs in Pakistan. The promotion of the IT sector is a key for the economic development of emerging markets due to its role for the globalization of markets and the host countries' local economic development (Dewan \& Kraemer, 2000; Leidner, 2010; Spence, 2004). Generally, emerging markets have a limited local capacity to develop new technology (Lall, 2000), therefore, these markets tend to rely largely on the external technology transfers as a main basis of imports of technology through FDI (Ivarsson \& Alvstam, 2005; Khan et al., 2015b). Accordingly, the role and impact of IT MNEs becomes more crucial in emerging countries. Despite the importance of the IT industry for Pakistani economy and the prevailing role of FDI in the IT services sector, the influence of FDI by IT MNEs in Pakistan has not been examined thoroughly. The paper focuses on the following two interrelated questions:

1. How IT Service MNEs impact the economic development in the host economy, notably through forming different types and intensity of linkages? and

2. What is the nature and scope of these linkages?

The findings suggest that IT service MNEs based in Pakistan have created various types of linkages such as managerial, technical, financial and diversification. These linkages have played an important role for the local economic development, and specifically, the development of the local software IT industry. One of the main findings of this study is that the creations of various linkages in the host market are contingent and co-determined by the motives, mandate and overall embeddedness of the MNEs in the host country as well as the local technical capability (e.g., Cantwell \& Mudambi, 2005). The findings further shed light on the key role of the host market's human capital and the overall environmental stability of 
the host market for attracting MNEs' centre of excellence and the development of various types of linkages.

The study makes three important contributions to the literature on linkages and the impact of MNEs on local economic development in the host economy. First, this paper contributes to the literature by documenting the impact of Service MNEs on local economic development, as most of the current research is on manufacturing MNEs. Second, this paper identifies both MNEs related and host country related factors that contribute to the formation and intensity of linkages in host markets. By doing so, it brings the MNEs' related attributes and the host market related factors together that provide a more fine-grained understanding of not only the formation but the intensity of linkages as well. Third, this is one of the first few studies on IT service MNEs in Pakistan, contributing to the FDI and development economics literature by studying the role of IT MNEs in Pakistan, as there are limited studies that examine the influence of MNEs in Pakistan by the economic development and IB literature.

\section{THEORETICAL BACKGROUND}

\section{FDI and its impact on host markets}

There are still ongoing debates on the impact of FDI on host markets (Kugler, 2006; Yamin \& Sinkovics, 2009), and so far the empirical evidence is mixed. Since Caves (1974), a lot of scholarly attention from the economic development to IB fields has taken place on identifying the impact of FDI on host markets (Meyer, 2004). Some scholars have documented the positive influence of MNEs on host markets (Blomström \& Kokko, 1998; Dunning, 1988, Keller \& Yeaple, 2009), for instance, Dunning (1988) notes that MNEs are accountable for the conduct of 80 percent of R\&D worldwide. Due to the possession of advanced technologies by MNEs, countries, specifically developing countries, encourage MNEs to invest in their markets in order to benefit from their advanced technologies and 
valuable knowledge (Blalock \& Gertler, 2008; Blomström \& Kokko, 1998; Glass \& Saggi, 1998; Meyer \& Sinani, 2009).

However, some authors have questioned the overall influence of FDI on the host markets. Rodrik (1999), notes, 'today's policy literature is filled with extravagant claims about positive spillovers from FDI, but the hard evidence is sobering'. In a similar vein, Aitken et al. (1997), and Aitken and Harrison (1999) suggest that the competition effect could be negative if MNEs take the market share from domestic firms and may even force the local firms to further cut their production. Girma, Greenaway and Wakelin (2001) and Sinani and Meyer (2004) also indicate that the employment effect of MNEs on the host economy may be negative if the MNEs hire the skilled workers, leaving the local firms to rely on low-skilled workers, terming it a market-stealing effect of MNEs on their host markets.

The lack of consensus about the benefits and drawbacks of FDI for host markets is seen to be as a result of the different ways of measuring FDI impacts on host markets (Pavlínek \& Žížalová, 2014). The context of the individual economies can also play an important role in terms of gaining benefits as well as drawbacks from FDI on host markets. The existing literature suggested that the impact of FDI on the local companies can be measured by four different mechanisms (e.g., Gorg \& Ruane, 2001). The first of these effects- imitation/ demonstration (Cheung \& Lin, 2004) results in which local firms observe the operations of MNEs and imitate their advanced technology. The second is called the competition effect. This takes place when MNEs enter in the host markets and impel local firms to improve production techniques (e.g., Markusen \& Venables, 1999; Wang \& Blomström, 1992). The third effects can take the form of linkages development in host markets, which is the main focus of this paper. For instance, domestic firms can learn from MNEs through business dealings or developing close business relationships with them (e.g., Blalock \& Gertler, 2008; Javorcik \& Spatareanu, 2008; Liu \& Buck, 2007). The last effect 
takes place through the mobility of a skilled labour force from MNEs to domestic firms (Blomström \& Kokko, 1998; Fosfuri, Motta \& Rønde, 2001; Kinoshita, 2001).

The above discussion clearly demonstrates the existence of several positive to negative effects of FDI by MNEs on host economies; therefore this scenario makes it difficult to have any viable expectations as to the overall impact of MNEs investment on host economies. In spite of this consensus, it is commonly assumed by policy makers that the effects of FDI in host markets are generally positive (Pavlínek \& Žížalová, 2014; Yao \& Wei, 2007). This specifically applies to the potential benefits of FDI in the form of technology transfer to host markets (Harding \& Javorcik, 2011). In this context, a better understanding of the effects of FDI is needed in host developing markets. Moreover, the focus in most prior research has been manufacturing MNEs and less attention has been paid to the service MNEs.

\section{Linkages development in service industry}

Typically, MNEs create and develop a portfolio of linkages with various local firms (e.g. suppliers, customers and competitors) in host markets. The portfolio of linkages takes place when MNEs develop transactional or partnerships with local firms as well as with local R\&D and training centres (Altenburg, 2000; Lall, 1980). Hirschman (1958) was one of the earlier scholars who documented such linkages in the field of economic development, which later on was investigated by various other streams of literature (e.g. Meyer, 2004). According to Lall (1980: 204), linkages refer to the "direct relationships established by firms in complementary activities which are external to 'pure' market transactions' in host markets". In this vein, linkages encompass longer-term as well as inter-firm transactions, collaborations and dynamic or continuing relationships between MNEs and local firms (UNCTAD, 2006). Most of the existing research has tried to examine the impact of the potential entry of MNEs on the local economic development of host markets. One line of research has specifically 
focused on understanding whether MNEs develop linkages in host markets, as local firms would benefit more through the establishment of the linkages by MNEs in local markets. In the context of FDI and inter-industry relationships, linkages can also lead to potentially beneficial impacts on the firms involved via spillovers (Görg \& Ruane, 2001).

Linkages strengthen the local economic development of the host markets through the transfer of valuable knowledge and management best practices (e.g., Ghauri \& Firth, 2011; Giroud \& Scott-Kennel, 2009; Javorcik, 2004, Osabutey, Williams \& Debrah, 2014; Takii, 2005). Linkages between MNEs and local firms are viewed positively for the local capability upgrading and industrial development in host markets by both policymakers and development economists (Lim \& Fong, 1982; Yao \& Wei, 2007), and their role has been suggested to be the key for the sustainable economic development of the host markets (e.g., Dunning \& Narula, 2005; UNCTAD, 2001). However, some scholars have questioned the impact of linkages on the local economic development as they offer limited opportunities for upgrading partner firms and local firms may get stuck in producing low value chain activities (Humphrey \& Schmitz, 2000, Gereffi, Humphrey \& Sturgeon, 2005).

The creations of linkage are categorized into vertical and horizontal (Javorcik, 2004). The vertical linkages are when direct relationships take place between local firms and the MNEs, whereas the horizontal ones result in the form of collaborative or inter-firm network relationships in the host markets. The linkage creation and patterns of linkages by MNEs on local economic development differ largely as it mainly depends on three elements: the industry, the MNEs, and the host economy (Lall, 1979:45). It is also about how well the local firms absorb the imported knowledge from MNEs (Cohen \& Levinthal, 1990). Within individual economies, linkages also depend on several other factors, such as the types of industry, the nature of operations of the MNEs, the technological gap between the foreign and host economy's firms and the duration of the FDI. These different determinants of linkages 
can lead to the establishment of a various dynamic patterns of linkage development in the host markets.

Above discussion on linkages from various fields of research however has been studied predominantly in the manufacturing industry. The main limitation of the current literature on linkages between MNEs and local firms is lack of empirical work in the service industry (Ghauri \& Firth, 2011). This was partly due to the fact that the service MNEs have a tendency to be not engaging with local suppliers and consequently limiting the overall linkage formation (Miozzo \& Grimshaw, 2008). Although the two broad categorization of linkages provide a useful basis for illustrating a spectrum of relationship of MNEs and local firms (Javorcik, 2004), the conceptualisation of linkages has been based on manufacturing MNEs largely. Moreover, existing literature is limited to take into consideration of the overall intensity of linkages coupled with the scope of linkages in the service sector (Giroud \& ScottKennel, 2006; Miozzo \& Grimshaw, 2008). Careful examination of the recent literature on linkages, Giroud and Scott-Kennel (2006; 2009) further identify and conceptualize the characteristics of linkage attributes focusing on scope, quantity and quality. Here, the level of linkage intensity, which includes the potential development for learning and improvement and intensity of inter-firm interaction, is determined by the scope, quantity and quality attributes. This perspective helps to build upon previous literature to offer a comprehensive analaysis of the linkage formation in the service industry. Thus, we draw from Giroud and Scott-Kennel's (2006; 2009) view of linkages to examine the service MNEs' linkages creation in the host market of Pakistan.

The reason why linkages become important within the context of service MNEs are that the nature of linkages in the service industry and service MNEs have evolved and created a prevailing role in many markets (Ghauri \& Firth, 2011). Specifically, we study the different types of linkage development in order to draw conclusions on the real impact of service 
MNEs on host markets. Here, we look at the procurement of material locally or the process being conducted in the local market, and the overall quality (depth) of linkages in regards to the value added potential of these linkages for the host markets' firms (e.g., Giroud \& ScottKennel, 2006). It is also important to understand the intensity of linkages in order to find out their impacts on the local economic development, as these can generate knowledge transfer and spillover to local firms. Based on the above discussion, Figure 1 illustrates our preliminary research framework.

[Insert Figure 1 about here]

\section{RESEARCH CONTEXT AND METHODS}

The IT sector is one of the important sectors in Pakistan, and has attracted substantial FDI in the range of over \$2.6 million between 2012-2014. The investment policies of Pakistan are business friendly in the region, as it offers $100 \%$ ownership equity to the foreign investors entering in the country. For example during July-March 2013-14, the government invested $\$ 0.55$ billion for the improvement of the IT-related infrastructure in the country (Pakistan Economic Survey, 2013-14). This suggests that the government of Pakistan is committed for developing the IT industry. Until now, we do not know enough about the influence of the MNEs operating in the IT sector on the local economic development of Pakistan. Some of the leading MNEs operating in this sector are the well-known brands and market leaders such as Microsoft, Siemens, NCR IBM, Cisco, SAP, Oracle and Intel and the firms have been doing business in Pakistan for quite some time.

These firms are playing an important role in helping the local software and business processing firms and streamlining the overall IT infrastructure of the country. These MNEs have witnessed a remarkable growth in their direct revenues in the country, thus highlighting the market potential of the country for their businesses. Some estimates suggest that some of 
these firms are generating over $\$ 260$ million per year from the Pakistani market. In addition to the direct contributions in the forms of high-value hardware/software as well as technological infrastructure, these firms are also playing a critical support role in supporting and upgrading the domestic IT market by generating intermediate product development opportunities for the local small and medium-sized software firms. Some of the supporting roles and activities in which these multinational routinely engage with local companies are explored in the findings section of the article.

In this study, we use an exploratory qualitative, interpretive research design, as most of the existing literature takes a quantitative approach investigating either the total factor productivity or labour productivity spillovers from FDI (e.g., Aitken \& Harrison, 1999; Keller \& Yeaple, 2009). Here, we explored the role of five major (see Table 1) IT MNEs established in the IT industry of Pakistan by utilizing a theoretical-purposive sampling strategy (e.g., Eisenhardt, 1989, Ghauri \& Gronhaug, 2010; Ghauri, 2004; Yin, 2003).

These five firms were selected as these are the largest firms operating in the IT industry, and these firms also expressed interest to take part in this research. In order to enhance the validity and transferability of our findings, we further interviewed four small Pakistani software companies to corroborate with the data obtained from the IT MNEs. The software firms were selected through the software export promotion board and Pakistan software houses association which keeps the information of its members. Again, these firms were selected due to their willingness to take part in this study. Table 1 provides background information of the selected companies. We developed an interview guide, and the data were collected through semi-structured interviews in order to get in-depth insights of the phenomenon under investigation (Eisenhardt, 1989). However, we kept this guide flexible and more questions were added as the interviews progressed.

[Insert Table 1 about here] 
During the entire process of data collection, various secondary sources were also utilized for triangulation purpose (Eishenhardt, 1989; Ghauri, 2004). These include local newspapers, publications related to the IT sector, as well as media reports. The triangulation approach is quite useful for the verification of data from multiple sources thus enhancing the trustworthiness of the findings. Some of the following questions were explored in these interviews: How has the firm transferred knowledge to the small local software firms? What type of products and services the companies offered in the local market? Does your company work with local software houses and IT related companies? What types of linkages your firm has established in the local market? To ensure reliability and establish data equivalence, interview questions were used in comparable manners and terminologies with all interviewees (Sinkovics, Penz \& Ghauri, 2005). We conducted seventeen face-to-face interviews with some of the top and middle managers of the selected firms between November 2011- January 2012. On average each interview lasted for 60-75 minutes and detailed notes were taken during the interviews. The interviews were recorded and fully transcribed afterwards. The summary of the interviews were shared with the interviewees to get their feedback and approval and this also further improved the reliability of the findings. Table 2 shows the profile of the respondents.

[Insert Table 2 about here]

\section{Data Analysis}

We utilized the established qualitative thematic open code content analysis techniques for the data analysis (Eishenhardt, 1989; Miles \& Huberman, 1994). First, we coded the individual interviews, and then we compared across the five firms, using cross-case analysis (Ghauri, 2004). The MNEs responses were compared with the four SMEs in order to develop a holistic picture about the data and emerging findings. For the purpose of the coding, we also utilized 
the preliminary research framework (Figure 1). We made constant comparisons of our findings with the literature on FDI and linkages. Through this approach, we identified different linkages that our respondents suggested and documented the findings of each company according to different linkages presented in Table 3. This table was later used for the cross-comparison purpose and within cases to develop a holistic picture about the findings (e.g., Eisenhardt, 1989; Ghauri, 2004). We also utilized the suggestions of Gioia, Corley, and Hamilton (2012) for categories and the subsequent themes. We compared the emerging themes with the existing literature on FDI, linkages and spillovers in order to develop a clear dialogue between the theory and our data.

[Insert Table 3 here]

\section{FINDINGS}

The findings suggest that the IT service MNEs have developed different types of linkages in the local market. These linkages are discussed below.

\section{Managerial linkages}

\section{Role in the development of human capital}

The findings suggest that the MNEs provided IT certificates, training and programs. It was one of the important linkage development in the country by these MNEs. For instance, the company A manager indicated that the company has established more than 52 IT networking training centres, providing support in different colleges and universities in the country and students are being trained to become certified IT networking engineers. Likewise, other firms' managers also suggested similar programs and one of the interviewees indicated:

Our firm is providing critical IT systems training to the local manpower and this training helps the trainees to seek and gain better employment opportunities in Pakistan. 
Similar views were expressed by other firms and one of the firm's manager suggested:

The firm operates an academy in the [Pakistani] market to train professionals in its proprietary ERP systems.

The data also suggest that all the five companies have set-up internship programs for the undergraduate students with some of the leading IT and Engineering Universities in Pakistan. These findings indicate that IT service MNEs are playing an important role to develop the human capital equipped with technical skills. This further suggests that service MNEs' knowledge exploitation motives are important for the development of human capital in the host market.

\section{Employment and development of talent effect}

The data suggest that these firms have created direct employment opportunities, leading towards the development of talent as one of the key managerial linkages in the local market. The findings indicate that the studied MNEs have also generated employment in the country through their direct competition with the local business process outsourcing and software firms. For example, these five firms employ more than 40,000 workers in the country. In addition to hiring from the local market, these MNEs recruit software developers from Pakistan to support their global operations. For instance, one of the firms hires nearly 45 IT and software engineers from the local universities to take up employment in the headquarters linked with major global operations. These firms highlighted their students' internship programs, as the key efforts of these firms in developing additional job opportunities in the country. One of firm's managers noted: 
Local talent is developed and nurtured by having internship schemes with the local universities and in this way more jobs opportunities are being created in the country.

These findings highlight the important role of these firms in developing human capital in the country through various programs.

\section{Development of regional centres of excellence}

Setting up the regional centre of excellence in the country has a connecting effect on the local market. The findings indicate that these MNEs are engaging with the host market through the establishment of regional centres of excellence and in some cases these centres are linked with their global high end service delivery operations. This effect is important for the domestic market, as it also helps in the development of local IT competencies. One of the leading firm's manager highlighted that her firm is planning to set up a virtual networking development centre in the domestic market, which will focus towards the Middle East market. However, the responses to establishing a regional centre of excellence in the country were somewhat mixed. The interviewees indicated:

Long-term involvement of the company in the local (Pakistani) market is one of the important considerations whether to setup a regional excellence centre in Pakistan or not.

\section{Technical linkages}

\section{Business support and development for the niche sub-industry sector}

The findings indicate that the IT service MNEs have not only helped in the development but also provided business support to the specialized software development niche cluster in Pakistan. This was the fourth most mentioned linkage highlighted by the respondents. For instance, one of the managers of the MNE said that his company played an important role for 
the set-up of local systems integration small and medium-sized companies in the country. Similar views were shared by other respondents in the following way:

Our firm has played an enabling role for providing support and development of local SMEs in developing and improving their data warehousing capabilities and by transferring knowledge to the local SMEs.

The findings also indicate that these MNEs have also helped the local small software companies to develop software for the local business needs. For instance, one of the managers indicated:

We have developed close linkages with the newly established software development houses that are developing customized products and hardware for the telecom sector. Our firm has helped and worked very closely with a newly established software house specializing in the development of mobile and handheld devices related software.

The findings also highlight that longevity of operations of the MNEs are playing an important role for the support being given to the local firms. The firms that are operating in the local market for a quite some time and have embedded within the business system were indicating more willingness to help the local firms rather than companies which have entered in the market after the 1990s. These findings indicate that MNEs' embeddedness and longevity in the local market are important factors for the development of linkages in their host countries.

\section{Product development partnerships and local firms' capability development}

The data suggest that the IT MNEs have developed product development partnerships with the local firms to support their capabilities development processes in Pakistan, consequently contributing to the local economic development. The findings also suggest that the MNEs are playing a vital role for the development of local companies' capabilities by developing joint 
product development alliances. For instance, one of the firm's manager noted his firm's joint product development alliance with the local companies that led not only for the transfer of valuable knowledge and key technology to them, but also resulted as additional revenue generations for the local company to sell the software both in the domestic as well as export to foreign markets. This was highlighted by our interviewee:

Building capabilities of local small software firms through partnerships with our firm has benefited the software companies not only to develop their product development capabilities but to extend their capabilities base in new software development for other sectors including banking and mobile commerce.

The findings further suggest that the deregulations of the financial sector and opening up the telecom sector for FDI have been imperative for the development of product development partnerships with the local Pakistani small software development companies. One of the managers noted:

Our company has established close product development partnership with local software development houses for the banking industry and local companies get useful know-how through these partnerships to augment their existing or to expand their IT capabilities.

These findings indicate the vital role of these MNEs for knowledge transfer and capabilities development of local firms through these linkages (Cohen \& Levinthal, 1990). These results further suggest that the MNEs willingness is important for the development of partnershiporiented and inter-connected linkages with local companies in the country. The establishment of partnership-oriented linkages in the host markets are costly and times consuming for 
MNEs' point of view, however these linkages are important for the host markets' economic development.

\section{Diversification-related linkages}

\section{Boundary spanners role of the IT service MNEs}

The findings indicate that the establishment of the diversification-related linkages for the growth of the local market were through boundary spanning activities of these MNEs. For example, $41 \%$ of the interviewees mentioned that the MNEs have performed their role as boundary spanning agents and helped the software and game development SMEs for internationalizing their operations in leading global markets. These MNEs facilitated the internationalization process of the Pakistani SMEs from the IT sector, for example, the game development companies were originally providing product support services to some of these MNEs in Pakistan and through these MNEs, the local SMEs got hooked up with their (MNEs) headquarters, and with their clients in the USA. This was by far the most important economic development impact of these MNEs in the host market. The country's director of one of the firm indicated:

The company has played an important role in helping two of the game development local firms [SMEs] for internationalization in the USA market.

The manager further highlighted the role of his firm by noting that firstly the two SMEs were providing services for the local subsidiary of the firm in the country and through the connections the firm facilitated two local small companies to find different product development projects in the USA market. These product development projects have been the key for the local companies to successfully establish their business in the USA market. 
Similar views about boundary spanners were expressed by other MNEs. For instance, our respondent indicated:

Our links and connections have been successfully utilized by some of our local software development firms to set up their operations in California. We helped these companies to get projects in the USA and these projects were important stepping stones for the local [firms] to internationalize into the USA market.

Taken together, these findings have important implications for Pakistan, and also for the internationalization literature, as majority of the existing studies have paid insufficient focus on the boundary spanning role of the MNEs in promoting the internationalization process of local SMEs. These findings were also supported by the managers of the local small firms:

We gather information for internationalizing into global markets through MNCs subsidiaries operating in our country and these [MNEs] have played a key facilitating role for our firm to internationalize. [Software development SMEs]

\section{Market related information and support for the local IT SMES}

The findings suggest that the five studied IT MNEs have created market awareness and provided support for the local SMEs by giving them market knowledge and necessary business support. The data indicate that by providing market information and support for the local SMEs was one of the key diversification linkages developed by the MNEs in the local market. For instance, one of the MNEs' manager indicated:

The [multinational] firm runs new market development and awareness programs for the [local] SMEs belonging to specific sectors for instance gaming development, financial service or systems integration to generate demand for their products and services both in the local and international markets. 
The findings also indicate that these companies have been playing an important role for promoting the local small software companies exports in global markets by providing them with key ideas on addressing quality related issues of their software. A MNEs manager suggested:

Our firm has played an important and vital role and been helping the local Pakistani [software] development enterprises on how to market their software in international markets, and we also work closely with the Pakistan software export promotion bureau to create opportunities for the local companies to market and export their products in international markets.

This kind of support seems to be important for the local small software development companies to gain foothold in international markets as the local institutional support is weak for the promotion of small firms' exports in international markets.

The managers of the local SMEs also indicated that their firms have acquired valuable knowhow and learned by tying up with the IT MNEs operating in the local market. One of the local game development SMEs' manager remarked:

We learned a lot being a service provider to some of the IT multinational companies based in Pakistan, and our links have been helpful for developing our capabilities to develop games. We have utilized the learning and revenue and start developing our own products. I don't think we would have been successful if we started outright with exporting our products without developing good interconnected [two-way] connections with the IT multinational companies operating in the local market.

\section{Financial linkages}

\section{Supporting the local innovation eco-systems}

The managers indicated that their firms have made important contributions to the countrywide innovation eco-systems. The data suggest that this support is provided by sponsoring IT 
related conferences, workshops, business plan competitions and software development between local entrepreneurs. The data indicate that the firms are also helping the local software industrial bodies in developing local peer-to-peer collaborations and social business events for the local IT business developers. A MNEs' manager suggested during the interviews that the firm has recently established an innovation centre in the industrial hub Karachi, Pakistan. This is the key centre established in the local market and across the globe. The manager indicated:

In [our] innovation and product development support centre, our company provides a free environment for software developers to get training, test their idea, refine their business concepts, and gain knowledge around software development and other IT-related products.

The managers also pointed out the firm has also established training agreements with the local universities to provide specialized training in order to support and encourage collaborations across the innovation eco-systems in the country.

\section{Key determinants for the creation of various types of linkages}

In regards to the overall linkages development in the country and the future strengthening of these linkages, the findings highlight some of important determinants from these MNEs' perspectives. Below we explore four of the key determinants.

\section{Embeddedness and mandates of the MNEs}

The managers we interviewed indicated that the development and further enhancement of the linkages are contingent and co-determined by the overall embeddedness and mandates of the MNEs in host markets (e.g., Cantwell \& Mudambi, 2005). The data indicate if the firm was doing business in the local market for a considerable time period, then, the company will 
develop both breadth and depth of linkages in host country. The longevity of the business in the local market was indicated by the interviewees as one of the key determinants for the development of various types of linkages.

\section{Local market potential and availability of talent}

The findings indicate that the local market potential and availability of the talented work force is one of the key determinants for establishing different types of linkages in the host market. The managers suggested that technically skilled human capital, growth potential and the size of the host market are also important considerations in order to attract good quality FDI and the development of various linkages in the host market from the MNEs' point of view.

The findings indicate the significance of technical human capital in producing different types of linkages via FDI in host markets. The firms that regarded the country as a key potential market and have a talent-based workforce and local potential were ready to expand their operations and strengthens their linkages compared to those firms that did not see any potential in the market or were newer to Pakistan.

\section{Perceived risk in the host market}

The third important determinant mentioned by the interviewees was the country's perceived risk and long-term perspectives of the local market in terms of security, political stability and protection of intellectual property rights for the development of different types of linkages. The interviewees suggested that external business condition and economic stability of the country is important for conducted valuable business activities in the market and to further strengthen the linkages with the local companies. Taken together, our findings are important for other emerging markets, as the economic stability and external conditions of these 
markets will have an impact on the degree to which MNEs can promote local economic development through inward FDI in the form of technological knowledge transfer to local firms.

\section{Technological capability}

The technical capability of the host market was another important factor. The managers indicated that their firms watch the host market's domestic technological capability for increasing/decreasing the scope of different types of linkages and the technical capability seems to be important for the knowledge exploitation in the market. One of the respondents suggested:

The setting up a development operation is important for the host market as this will generate a real impact on the development of talent pools. For a world class development centre, the host market needs to have a good skill-based workforce and IT infrastructures and we do see a potential in the [Pakistani] market as there are lots of young talented IT graduates, so, for us to set up such [development] centre, I think the host market engineering capabilities and infrastructures are important.

Another manager summed up in the following way:

Ireland has developed its technology capability and has attracted major MNCs in the IT industry. Their [Ireland] whole industry is developed around having the technology capabilities and MNCs have developed good links with the local Irish companies. The key message is that the host country's capability and quality of human resources are important to generate benefits through MNCs. 
The data also indicate that the local capabilities in different areas from software development to conducting R\&D activities are important determinants for extending different types of linkages in the host market through IT service MNEs' investment. These findings are consistent with the scholars suggesting that domestic capabilities are important to gain benefits from MNEs (e.g., Rasiah \& Xiao Shan, 2016, Meyer \& Sinani, 2009).

\section{DISCUSSION AND CONCLUSIONS}

The aim of this paper was to investigate the influence of inward FDI on the economic development of the late liberalizing economy of Pakistan by taking the example of IT service MNEs. Most of the existing literature from the international business and strategy has investigated the consequences and motivation of FDI. There is an emergent literature focusing on the influence of FDI on the economic development of host markets (Park \& Ghauri, 2011). However, the existing literature does not provide any conclusive answer to the impact of MNEs on the host economies. Some studies note a positive impact, whereas others suggest a negative impact of MNEs on the economic development of local markets. Most of the existing studies are quantitative in nature and have mainly focused their attention on understanding FDI related spillovers in the forms of either total factor productivity or labour productivity mainly in the manufacturing industry (Keller \& Yeaple, 2009; Aitken \& Harrison, 1999). In order to examine the influence of FDI on the economic development of host markets, we investigated the development of linkages by the IT service MNEs in Pakistan, taking a qualitative exploratory approach.

The findings indicate that IT service MNEs operating in Pakistan have developed different types of linkages and the development of these linkages were contingent and codetermined by the MNEs related factors such as the motives of these MNEs, local technical capability, and the mandates and embeddedness of the MNEs. The MNEs developed various 
linkages such as managerial, technical, diversification-related and financial, and these have played an important role for the economic development of Pakistan. The companies have provided software development and certification training in the country to develop the local technical labor force. The training impact of MNEs is important in the context of the emerging economies, as the emerging economies have weak skill-based systems and inefficient training providing institutions, thus, the support coming from the MNEs is one of the key enablers for developing local capabilities (e.g., Cohen \& Levinthal, 1990).

The findings suggest that these firms have also facilitated some of the local SMEs to internationalize into USA. This boundary spanning role of the IT service MNEs is important for the local companies to successfully internationalize and generate revenue through internationalization (Khan et al., 2015a). This is perhaps one of the important findings in the context of the economic development of the host market, as the extant SMEs' internationalization literature has not fully explored the boundary spanning role of the MNEs for the internationalization of local SMEs (e.g., Prashantham \& Dhanaraj, 2014).

The findings also highlight that the MNEs have also established product development linkages with the local small IT companies. These partnerships are important for the local companies to benefit from knowledge transfer from the MNEs, thus this could help local companies to develop their absorption capacity (e.g. Cohen \& Levinthal, 1990). Particularly, product development alliances are beneficial for the local companies to develop other relevant software for the MNEs and different sectors, for example financial services and telecommunications. This finding is consistent with the work of Hobday (1995), suggesting that MNEs entry into different industries in Taiwan led to the increase in demand for intermediate goods, and this resulted in the increase of total factor productivity amongst local companies. 
The data suggest that the MNEs have played an important role for the development of the niche sub-sector industry in the country. The firms have developed local technical systems integration and data warehousing start-ups by transferring the key know-how and the companies are playing a key role for the development of local capabilities. The findings therefore support the views of various scholars that have noted the positive impact of MNEs in the form of capability development of local firms (e.g., Giroud, 2007; Lall, 1980; Okada, 2004). Generally, the findings of these studies are somewhat mixed, however, there is a wider agreement in the literature that local firms' capability development is one of the important benefits of MNEs on host markets.

\section{Linkages are contingent and co-determined by various interrelated factors}

While the core linkages in the forms of financial, managerial, technical, and diversification-related in this paper seemed to support the existing literature on linkages through FDI, Figure 2 differs from the preliminary framework to demonstrate the MNEs related attributes and host market- related factors that interact with each other to influence the intensity and nature of linkages development in host markets.

The findings suggest that both MNEs related and host country related factors may either generate thin or thick linkages in host markets (see Table 3 and Figure 2). Previous research often fails to bring these two important attributes together, for instance the MNEs-related and the host market-related factors that can influence not only the formation of linkages but the intensity of linkages as well. Therefore, this paper extends understanding about the dynamic nature of factors both from the MNEs' side as well as the host country side that facilitate the formation of linkages. Most of the existing research tends to focus more on the host country and local firms related factors that influence the creations of linkages in host markets (e.g., Belderbos, Capannelli \& Fukao, 2001; Chen, Chen \& Ku, 2004). The findings indicate that the nature and different types of linkages reflect a combination of factors. Based on the 
findings, Figure 2 elucidates different types of linkages highlighting MNEs-related factors such as the embeddedness and mandates of the MNEs and host market-related factors for instance local market potentials and technical human capital, environmental risk and technology capability of host market that may facilitate or hinder the development of breadth and depth of linkages in host markets.

[Figure 2 here]

As our study indicates, it is important to understand the MNEs' linkage development in the host markets by paying attention to their sourcing of material or the process being undertaken by these firms in the local market as well as the thickness of linkages in terms of their potential for value added to the local market (e.g., Miozzo et al., 2012). The findings indicate that the development of different types of linkages in the local market are dependent on the motives of MNEs, technological capability of the host market, and the mandate and overall embeddedness of MNEs in the local market (Cantwell \& Mudambi, 2005). These findings echo the views highlighted in the recent studies indicating that the scales and nature of the operations of service MNEs and the subsidiary embeddedness in host markets reflect the subsidiary autonomy and local partnerships (e.g., Miozzo \& Yamin, 2012; Martin \& Bell, 2006). Overall, the findings highlight that the MNEs operating in the IT industry of Pakistan have developed a range of linkages and these linkages are contributing to the development of the local IT sector. The linkages are also strengthening the e-commerce sector, as there is a great potential of e-commerce in the country due to the emergence of middle class and young talent in the IT sector.

\section{Summary of contributions}

There is a growing interest in understanding the impact of MNEs on host markets (e.g., Meyer, 2004; Haskel, Pereira \& Slaughter, 2007; Park \& Ghauri, 2011). Existing 
research documents both positive and negative influence of MNEs on local economic development. This paper makes three important contributions to the existing debate on the impact of MNEs on local economic development. First, it investigates IT service MNEs' linkages (e.g., Lahiri et al., 2014, Kundu \& Merchant, 2008; Miozzo et al., 2012; Miozzo \& Yamin, 2012), as majority of the existing research focuses on manufacturing MNEs. Second, it identifies the attributes of the MNEs and host country-related factors that enable the formation and intensity of linkages in the host market (see Figure 2). One of the key contributions is that the development of the linkages in the host market are contingent and codetermined by the motives of the IT service MNEs, local technical capability, the mandates and embeddedness of the MNEs. By doing so, it brings the MNEs' related attributes and the host market-related factors together, which provides a more fine-grained understanding of not only the formation but the intensity of linkages (e.g., Miozzo et al., 2012; Lall, 1980). Third, it provides important insights from one of the least researched country (e.g., Pakistan), thus it brings an important context in the domain of international business literature.

\section{Implications for policy makers}

The study offers important guidelines for policy makers to harness the positive benefits through FDI. First, we identify that local technical human capital development is important for attracting good quality FDI that can generate various linkages in the local market. Keeping this in mind, the policy makers should invest in improving the local capability infrastructures such as investing in education, improving the engineering base and human resource training in order to benefit from FDI. Second, the findings suggest that the stability of the external environment is important for the development of the linkages through MNEs. The policy makers should pay attention to improve the country level external environments by strengthening the political and legal systems of the country in order to benefit from the MNEs. Lastly, the policy makers should promote MNEs-local SMEs' partnerships and local 
SMEs-SMEs links that can provide credible learning in order to develop the countrywide innovation eco-systems.

\section{Limitations and future research directions}

Given the exploratory nature of this study, there are several limitations that can serve as directions for the future research. First, we use qualitative data and take only the perspectives of MNEs from the IT sector of Pakistan, however, the MNEs responses were cross-checked with local SMEs operating in the software sector. It would be interesting to find a pair matched-local companies with the foreign MNEs to gauge the real impacts of FDI on host markets. Second, we investigated different types of linkages and effects of MNEs in the host market. Future studies could investigate other impacts as well, including productivity and labour mobility effects of MNEs on local companies by deploying panel-data techniques. Similar approach could be applied to study the impact of emerging economies' investment in developed markets, as recently we have seen a surge of emerging economies' investment in both developed and developing markets.

Lastly, we investigated the linkages development of only five MNEs from the IT industry of Pakistan. Future studies need to do a comparison of manufacturing and service MNEs influencing the host markets in various emerging economies prevailed in Asia, Latin America and Africa, so the generalization can be established.

\section{REFERENCES}

Aitken, B.J., \& Harrison, A.E. (1999). Do domestic firms benefit from direct foreign investment? Evidence from Venezuela. American Economic Review, 89(3): 605-618.

Aitken, B.J., Hanson, G.H., \& Harrison, A.E. (1997). Spillovers, foreign investment, and export behavior. Journal of International Economics, 43, 103-132.

Altenburg, T. (2000). Linkages and spill-overs between transnational corporations and small and medium-sized enterprises in developing countries: opportunities and policies: in 
unctad, tnc-sme linkages for development: issues-experiences-best practices. New York:United Nations, 2000, pp. 3-61.

Belderbos, R., Capannelli, G., \& Fukao, K. (2001). Backward vertical linkages of foreign manufacturing affiliates: Evidence from Japanese multinationals. World Development, 29, 189-208.

Blalock, G., \& Gertler, P.J. (2008). Welfare gains from foreign direct investment through technology transfer to local suppliers. Journal of International Economics, 74, 402421.

Blomström, M., \& Kokko, A. (1998). Multinational corporations and spillovers. Journal of Economic Surveys, 12, 247-277.

Cantwell, J., \& Mudambi, R. (2005). MNE competence-creating subsidiary mandates. Strategic Management Journal, 26, 1109-1128.

Caves, R.E. (1974). Multinational firms, competition, and productivity in host-country markets. Economica, 176-193.

Chang, H.-J. (2004). Globalization, economic development and the role of the state. London, New York: Zed Books.

Cheng, Y. (2006). Determinants of FDI mode choice: Acquisition, brownfield, and greenfield entry in foreign markets, Canadian Journal of Administrative Sciences, 23(3), 202220.

Chen, T.-J., Chen, H., \& Ku, Y.-H. (2004). Foreign direct investment and local linkages. Journal of International Business Studies, 35, 320-333.

Cheung, K.-Y., \& Lin, P. (2004). Spillover effects of fdi on innovation in china: evidence from the provincial data. China Economic Review, 15, 25-44.

Cohen, W.M., \& Levinthal, D.A. (1990). Absorptive capacity: a new perspective on learning and innovation. Administrative Science Quarterly, 35, 128-152. 
Dewan, S., \& Kraemer, K.I. (2000). Information technology and productivity: evidence from country-level data. Management Science, 46, 548-562.

Dunning, J.H. (1988). Explaining international production, Unwin Hyman London.

Dunning, J.H., \& Narula, R. (2005). Multinationals and industrial competitiveness: a new agenda, Cheltenham, Edward Elgar Publishing.

Dunning, J.H., \& Lundan, S. (2008). Multinational enterprises and the global economy, (2nd ed.). Cheltenham: Edward Elgar.

Eisenhardt, K.M. (1989). Building theories from case study research. Academy of Management Review, 14, 532-550.

Forsgren, M., Holm, U., \& Johanson, J. (2005). Managing the embedded multinational: a business network view, Cheltenham, UK: Edward Elgar Publishing.

Fosfuri, A., Motta, M., \& Rønde, T. (2001). Foreign direct investment and spillovers through workers' mobility. Journal of International Economics, 53, 205-222.

Gereffi, G., Humphrey, J., \& Sturgeon, T. (2005). the governance of global value chains. Review of International Political Economy, 12, 78-104.

Ghauri, P. (2004). Designing and conducting case studies in international business research, in R. Marschan-Piekkari \& C. Welch (eds.), Handbook of qualitative research methods for international business (pp. 109-124). Cheltenham, UK \& Northampton, USA: Edward Elgar Publishing.

Ghauri, P., \& Gronhaug, K. (2010). Research methods in business studies 4th edition, Pearson Education Limited.

Ghauri, P.N., \& Firth, R. (2011). The impact of foreign direct investment on local firms: Western firms in emerging markets. Research in Global Strategic Management, 15, $379-405$. 
Gioia, D.A., Corley, K.G., \& Hamilton, A.L. (2012). Seeking qualitative rigor in inductive research: Notes on the Gioia methodology. Organizational Research Methods, 16, 153.

Girma, S., Greenaway, D., \& Wakelin, K. (2001). who benefits from foreign direct investment in the uk? Scottish Journal of Political Economy, 48, 119-133.

Giroud, A. (2003). Transnational corporations, technology, and economic development: Backward linkages and knowledge transfer in South East Asia. Cheltenham and Northampton: Edward Elgar.

Giroud, A. (2007). MNEs vertical linkages: the experience of vietnam after malaysia. International Business Review, 16, 159-176.

Giroud, A., \& Scott-Kennel, J. (2006). foreign-local linkages in international business: a review and extension of the literature, bradford university, school of management.

Giroud, A., \& Scott-Kennel, J. (2009). MNE linkages in international business: a framework for analysis. International Business Review, 18, 555-566.

Glass, A.J., \& Saggi, K. (1998). International technology transfer and the technology gap. Journal of Development Economics, 55, 369-398.

Görg, H., \& Ruane, F. (2001). Multinational companies and linkages: panel-data evidence for the irish electronics sector. International Journal of the Economics of Business, 8, 118.

Ha, Y.J., \& Giroud, A. (2015). Competence-creating subsidiaries and FDI technology spillovers, International Business Review, 24, 605-614.

Haddad, M., \& Harrison, A. (1993). Are there positive spillovers from direct foreign investment?: evidence from panel data for morocco. Journal of Development Economics, 42, 51-74.

Hansen, M.W., Pedersen, T., \& Petersen, B. (2009). MNC strategies and linkage effects in developing countries. Journal of World Business, 44, 121-130. 
Harding, T., \& Javorcik, B.S. (2011). Roll out the red carpet and they will come: investment promotion and fdi inflows. The Economic Journal, 121, 1445-1476.

Haskel, J.E., Pereira, S.C., \& Slaughter, M.J. (2007). Does inward foreign direct investment boost the productivity of domestic firms?. The Review of Economics and Statistics, 89, 482-496.

Hirschman, A.O. (1958). The strategy of economic development, Yale University press New Haven, CT.

Hobday, M. (1995). East asian latecomer firms: learning the technology of electronics. World Development, 23, 1171-1193.

Humphrey, J., \& Schmitz, H. (2000). governance and upgrading: linking industrial cluster and global value chain research, Institute of Development Studies Brighton.

Iguchi, C. (2012). Globalisation of r\&d by tnc subsidiaries: the case of south-east asian countries. Asian Business \& Management, 11, 79-100.

Ivarsson, I., \& Alvstam, C.G. (2005). Technology transfer from tncs to local suppliers in developing countries: a study of ab volvo's truck and bus plants in brazil, china, india, and mexico. World Development, 33, 1325-1344.

Javorcik, B.S. (2004). Does foreign direct investment increase the productivity of domestic firms? in search of spillovers through backward linkages. American Economic Review, 94, 605-627.

Javorcik, B.S., \& Spatareanu, M. (2008). To share or not to share: does local participation matter for spillovers from foreign direct investment? Journal of Development Economics, 85, 194-217.

Jindra, B., Giroud, A., \& Scott-Kennel, J. (2009). Subsidiary roles, vertical linkages and economic development: lessons from transition economies. Journal of World Business, 44, 167-179. 
Keller, W., \& Yeaple, S.R. (2009). multinational enterprises, international trade, and productivity growth: firm-level evidence from the united states. The Review of Economics and Statistics, 91, 821-831.

Khan, R.E.A., \& Nawaz, M.A. (2010). Economic determinants of Foreign direct investment in Pakistan. Journal of Economics, 1, 99-104.

Khan, Z., Lew, Y.K. and Sinkovics, R.R. (2015a). International joint ventures as boundary spanners: technological knowledge transfer in an emerging economy. Global Strategy Journal, 5,48-68.

Khan, Z., Shenkar, O., \& Lew, Y.K. (2015b). Knowledge transfer from international joint ventures to local suppliers in a developing economy. Journal of International Business Studies, 46, 656-675.

Kinoshita, Y. (2001). R\&D and technology spillovers through fdi: innovation and absorptive capacity. CEPR Discussion Papers.

Kugler, M. (2006). Spillovers from foreign direct investment: within or between industries? Journal of Development Economics, 80, 444-477.

Kundu, S.K., \& Merchant, H. (2008). Service multinationals: their past, present, and future. Management International Review, 48, 371-377.

Lahiri, S., Elango, B., \& Kundu, S.K. (2014). Cross-border acquisition in services: Comparing ownership choice of developed and emerging economy MNEs in India. Journal of World Business, 49, 409-420.

Lall, S. (1979). The international allocation of research activity by us multinationals. Oxford Bulletin of Economics and Statistics, 41, 313-331.

Lall, S. (1980). Vertical inter-firm linkages in LDCs: An empirical study. Oxford Bulletin of Economics and Statistics, 42(3), 203-226. 
Lall, S. (2000). The technological structure and performance of developing country manufactured exports, 1985-98. Oxford Development Studies, 28, 337-369.

Leidner, D.E. (2010). Gobalization, culture, and information: towards global knowledge transparency. The Journal of Strategic Information Systems, 19, 69-77.

Lim, L.Y., \& Fong, P.E. (1982). Vertical linkages and multinational enterprises in developing countries. World Development, 10, 585-595.

Liu, X., \& Buck, T. (2007). innovation performance and channels for international technology spillovers: evidence from chinese high-tech industries. Research Policy, $36,355-366$.

Markusen, J.R., \& Venables, A.J. (1999). Foreign direct investment as a catalyst for industrial development. European Economic Review, 43, 335-356.

Meyer, K.E. (2004). Perspectives on multinational enterprises in emerging economies. Journal of International Business Studies, 35, 259-276.

Meyer, K.E., \& Sinani, E. (2009). When and where does foreign direct investment generate positive spillovers\&quest; a meta-analysis. Journal of International Business Studies, 40, 1075-1094.

Nicolini, M., \& Resmini, L. (2010). FDI spillovers in new EU member states: which firms create them and which firms really benefit? Economics of Transition, 18(3), 487-511.

Miles, M.B., \& Huberman, A.M. (1994). Qualitative Data Analysis. Thousand Oaks, CA: Sage Publications.

Miozzo, M., \& Grimshaw, D. (2008). Service multinationals and forward linkages with client firms: the case of it outsourcing in argentina and brazil. International Business Review, 17, 8-27.

Miozzo, M., \& Yamin, M. (2012). Institutional and sectoral determinants of headquarterssubsidiary relationships: A study of UK service multinationals in China, Korea, Brazil and Argentina. Long Range Planning, 45, 16-40. 
Miozzo, M., Yamin, M., \& Ghauri, P.N. (2012). Strategy and structure of service multinationals and their impact on linkages with local firms. The Service Industries Journal, 32, 1171-1191.

Okada, A. (2004). Skills development and inter-firm learning linkages under globalization: Lessons from the Indian automobile industry. World Development, 32, 1265-1288.

Osabutey, E.I., Williams, K., \& Debrah, Y.A. (2014). The potential for technology and knowledge transfers between foreign and local firms: a study of the construction industry in Ghana. Journal of World Business, 49, 560-571.

Pakistan Economic Survey (2013-14). Ministry of Finance, Government of Pakistan, Islamabad.

Park, B.I., \& Ghauri, P.N. (2011). Key factors affecting acquisition of technological capabilities from foreign acquiring firms by small and medium sized local firms. Journal of World Business, 46, 116-125.

Pavlínek, P., \& Zížalová, P. (2014). Linkages and spillovers in global production networks: firm-level analysis of the czech automotive industry. Journal of Economic Eeography.

Prashantham, S., \& Dhanaraj, C. (2014). MNE ties and new venture internationalization: exploratory insights from india. Asia Pacific Journal of Management, 1-24.

Rasiah, R., \& Xiao Shan, Y. (2016). Institutional support, technological capabilities and domestic linkages in the semiconductor industry in Singapore. Asia Pacific Business Review, 22,180-192.

Rodrik, D. (1999). The new global economy and developing countries: making openness work, policy essay 24, overseas development council Johns Hopkins University Press, Washington, DC.

Santangelo, G.D. (2009). MNCs and linkages creation: Evidence from a peripheral area. Journal of World Business, 44, 192-205. 
Sinani, E., \& Meyer, K.E. (2004). Spillovers of technology transfer from fdi: the case of Estonia. Journal of Comparative Economics, 32, 445-466.

Sinkovics, R.R., Penz, E., \& Ghauri, P. N. (2005). Analysing textual data in international marketing research. Qualitative Market Research: An International Journal, 8, 9-38.

Smeets, R. (2008). Collecting the pieces of the fdi knowledge spillovers puzzle. The World Bank Research Observer, 23, 107-138.

Spence, M. (2004). Efficiency and personalization as value creation in internationalisng hightechnology SMEs, Canadian Journal of Administrative Sciences, 21(1), 65-78.

Takii, S. (2005). Productivity spillovers and characteristics of foreign multinational plants in indonesian manufacturing 1990-1995. Journal of Development Economics, 76, 521542.

UNCTAD. (2001). World investment report., New York: United Nations.

UNCTAD. (2006). World investment report. New York: United Nations.

UNCTAD. (2014). World investment report. investing in the sdgs: an action plan. United Nations. New York and Geneva.

Wang, J.Y., \& Blomström, M. (1992). Foreign investment and technology transfer: a simple model. European Economic Review, 36, 137-155.

$\mathrm{Xu}, \mathrm{B}$. (2000). Multinational enterprises, technology diffusion, and host country productivity growth. Journal of Development Economics, 62, 477-493.

Yamin, M., \& Sinkovics, R.R. (2009). Infrastructure or foreign direct investment?: an examination of the implications of mne strategy for economic development. Journal of World Business, 44, 144-157.

Yao, S., \& Wei, K. (2007). Economic growth in the presence of fdi: the perspective of newly industrialising economies. Journal of Comparative Economics, 35, 211-234.

Yin, R., (2003). Case study research; designs and method, 3rd ed., Thousand Oaks, CA: Sage

\section{Publications.}


Table 1 Characteristics of five case firms

\begin{tabular}{|l|l|l|l|l|}
\hline $\begin{array}{l}\text { Case } \\
\text { firms }\end{array}$ & $\begin{array}{l}\text { Year of } \\
\text { entry } \\
\text { into } \\
\text { Pakistan }\end{array}$ & $\begin{array}{l}\text { Home } \\
\text { country }\end{array}$ & $\begin{array}{l}\text { No. of } \\
\text { employees }\end{array}$ & Industry and activity \\
\hline A & 1990 & USA & 12000 & $\begin{array}{l}\text { IT: Enterprise and industry solutions, Training } \\
\text { \& IT certification, server and cloud computing, } \\
\text { Consultancy services }\end{array}$ \\
\hline B & 1952 & USA & 15000 & $\begin{array}{l}\text { IT: IT services, business continuity \& resiliency } \\
\text { services, and Business Consultancy, CRM }\end{array}$ \\
\hline C & 2005 & USA & 1200 & $\begin{array}{l}\text { IT: Point of Sale hardware and software, ATMs, } \\
\text { Kiosks, Enterprise management, online banking, } \\
\text { Consulting services, software development, } \\
\text { education centre computing and technology } \\
\text { services }\end{array}$ \\
\hline D & 2007 & USA & 8000 & $\begin{array}{l}\text { IT: Operating systems services, Java Security, } \\
\text { Certifications, Web commerce, E-business suite, } \\
\text { Financial applications, Enterprise resource } \\
\text { planning, CRM }\end{array}$ \\
\hline E & 1947 & Germany & 6000 & $\begin{array}{l}\text { IT: Automation services, Asset management, } \\
\text { Technical consulting and engineering support, } \\
\text { Modernization \& optimization services, } \\
\text { hardware \& turn key infrastructure solutions, } \\
\text { Business consulting, ERP solutions, SAP } \\
\text { training }\end{array}$ \\
\hline
\end{tabular}

Table 2 Interviewees profile (case firms A-E)

\begin{tabular}{|c|c|c|}
\hline $\begin{array}{l}\text { Case } \\
\text { firms }\end{array}$ & Interviewees & $\begin{array}{l}\text { No. of interviews } \\
\text { conducted }\end{array}$ \\
\hline A & $\begin{array}{ll}\text { - } & \text { Country Manager } \\
\text { - } & \text { Sales Manager } \\
\text { - } & \text { Product development Manager }\end{array}$ & 4 \\
\hline B & - Economic development manager & 3 \\
\hline $\mathrm{C}$ & - Corporate Strategy Manager & 2 \\
\hline $\mathrm{D}$ & $\begin{array}{l}\text { - Business Development Manager } \\
\text { - Regional Director }\end{array}$ & 5 \\
\hline $\mathrm{E}$ & $\begin{array}{l}\text { - Vice President Operations } \\
\text { - Country Manager }\end{array}$ & 3 \\
\hline
\end{tabular}

Table 3 Types of linkages, themes and categories across firms

\begin{tabular}{|l|l|r|}
\hline $\begin{array}{l}\text { Types of } \\
\text { linkage } \\
\text { creations }\end{array}$ & $\begin{array}{l}\text { MNEs impact } \\
\text { and linkage } \\
\text { themes }\end{array}$ & Linkages specific examples across five IT MNEs \\
\hline $\begin{array}{l}\text { Managerial } \\
\text { linkage }\end{array}$ & $\begin{array}{l}\text { Human capital } \\
\text { development }\end{array}$ & $\begin{array}{l}\text { Provision of IT related training and } \\
\text { professional IT certificates } \\
\text { - }\end{array}$
\end{tabular}




\begin{tabular}{|c|c|c|}
\hline & & $\begin{array}{ll} & \text { Universities } \\
\text { - } \quad \text { IT oriented internship programmes }\end{array}$ \\
\hline & $\begin{array}{l}\text { Employment and } \\
\text { development of } \\
\text { Talent impact }\end{array}$ & $\begin{array}{l}\text { - } \begin{array}{l}\text { Creation of direct employment for IT } \\
\text { graduates }\end{array} \\
\text { - Development of Talent through software and } \\
\text { extreme programming competition in the local } \\
\text { universities } \\
\text { - Development of internship programs }\end{array}$ \\
\hline & $\begin{array}{l}\text { Setting up } \\
\text { regional centre } \\
\text { of excellence }\end{array}$ & $\begin{array}{l}\text { - Setting up a regional virtual networking centre } \\
\text { in the local market } \\
\text { - Local capabilities are vital for the attraction of } \\
\text { such a centre }\end{array}$ \\
\hline \multirow[t]{2}{*}{$\begin{array}{l}\text { Technical } \\
\text { linkage }\end{array}$} & $\begin{array}{l}\text { Development } \\
\text { and business } \\
\text { support for the } \\
\text { niche IT sub- } \\
\text { sector }\end{array}$ & $\begin{array}{l}\text { - Developing data warehousing capabilities and } \\
\text { support for the sub-sector. } \\
\text { Close connections with the software houses to } \\
\text { develop specific software for the telecom and } \\
\text { banking sectors. }\end{array}$ \\
\hline & $\begin{array}{l}\text { Local firms } \\
\text { capability } \\
\text { development } \\
\text { impact }\end{array}$ & $\begin{array}{l}\text { - Product development partnerships with the } \\
\text { local IT companies. } \\
\text { - Transfer of knowledge through these } \\
\text { partnerships }\end{array}$ \\
\hline \multirow[t]{2}{*}{$\begin{array}{l}\text { Diversification- } \\
\text { related linkage }\end{array}$} & $\begin{array}{l}\text { Boundary } \\
\text { spanning impact }\end{array}$ & $\begin{array}{l}\text { Facilitating IT SMEs internationalization } \\
\text { through social networking and boundary } \\
\text { spanning } \\
\text { - Finding projects for local SMEs in the MNEs } \\
\text { home market }\end{array}$ \\
\hline & $\begin{array}{l}\text { Market } \\
\text { information and } \\
\text { support for the } \\
\text { IT companies }\end{array}$ & $\begin{array}{l}\text { - Helping local IT SMEs how to market and } \\
\text { promote their products for the home and } \\
\text { international markets }\end{array}$ \\
\hline $\begin{array}{l}\text { Financial } \\
\text { linkage }\end{array}$ & $\begin{array}{l}\text { Support for the } \\
\text { local innovation } \\
\text { eco-system }\end{array}$ & $\begin{array}{l}\text { - } \quad \text { Development of innovation centre } \\
\text { - Organizing IT conferences } \\
\text { - } \quad \text { Supporting business plan competition } \\
\text { - } \quad \text { Supporting SMEs-to-SMEs collaborations }\end{array}$ \\
\hline
\end{tabular}




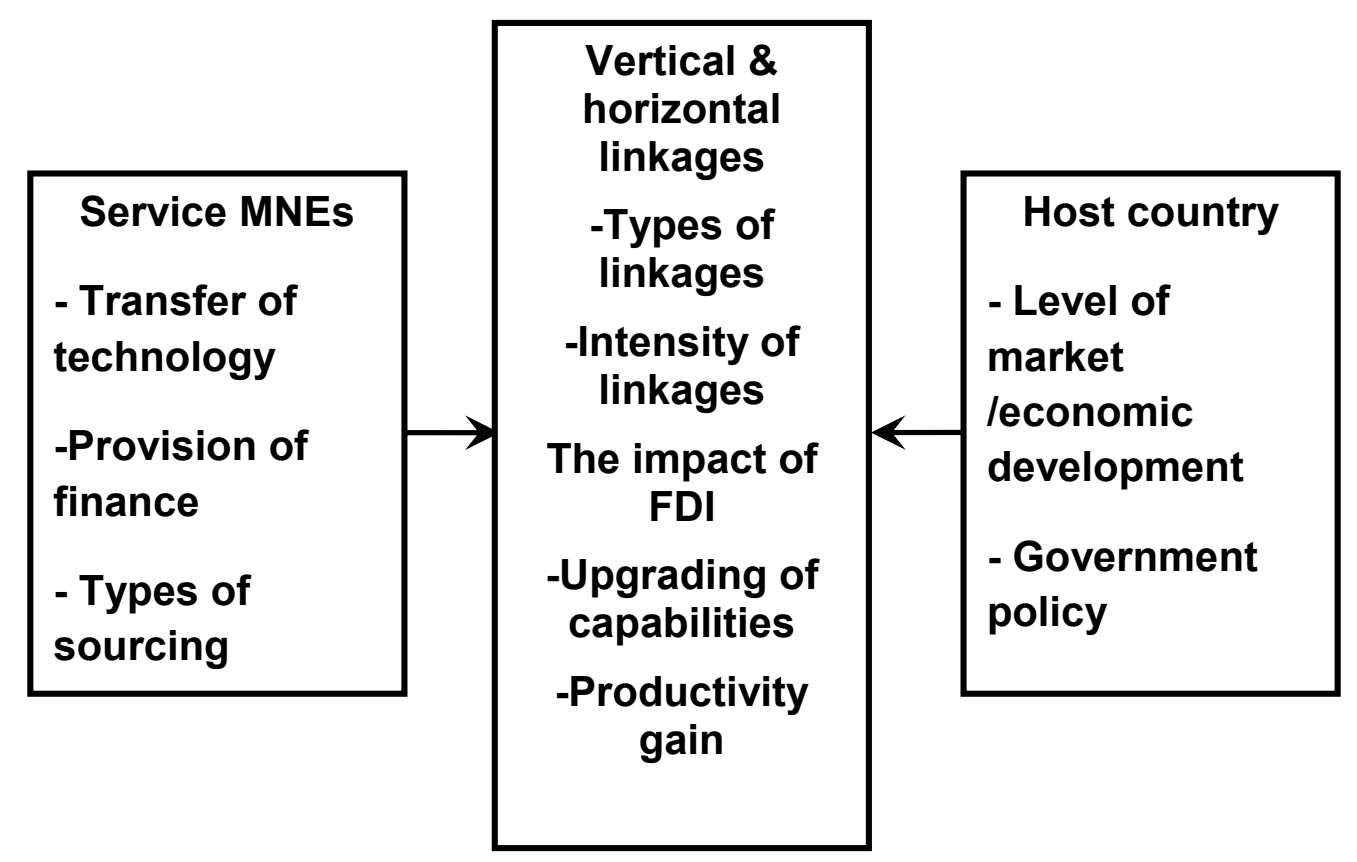

Figure 1. Preliminary framework of linkages

\begin{tabular}{|c|c|c|}
\hline $\begin{array}{l}\text { MNEs specific } \\
\qquad \text { attributes } \\
\text { - Embeddedness } \\
\text { and mandates of } \\
\text { the MNEs in the } \\
\text { market }\end{array}$ & $\begin{array}{l}\text { Types of linkage } \\
\text { creations } \\
\text { - Managerial } \\
\text { - Technical } \\
\text { - Diversification } \\
\text { - Financial }\end{array}$ & $\begin{array}{l}\text { Host country } \\
\quad \text { specific } \\
\quad \text { attributes } \\
\text { - Market Potential } \\
\text { and availability of } \\
\text { Talent } \\
\text { - Perceived Risk in } \\
\text { the host market } \\
\text { - Technology } \\
\text { Capability }\end{array}$ \\
\hline
\end{tabular}

Figure 2. MNEs and host country specific attrtibutes influencing linkage creations 